\title{
Analysis of ANFIS MPPT Controllers for Partially Shaded Stand Alone Photovoltaic System with Multilevel Inverter
}

\author{
T. Ramesh ${ }^{1}$, R. Saravanan ${ }^{2}$, S. Sekar ${ }^{3}$ \\ ${ }^{1,3}$ Department of EEE, Karpagam Academiy of Higher Education, Coimbatore, Tamil Nadu, India \\ ${ }^{2}$ Department of Electrical and Electronics Engg, Tirumala Engineering College, Bogaram, Telengana, India
}

\begin{tabular}{l} 
Article Info \\
\hline Article history: \\
Received Mar 11, 2018 \\
Revised May 12, 2018 \\
Accepted May 26, 2018 \\
\hline
\end{tabular}

Keyword:

ANFIS

Boost converter

MPPT control

\begin{abstract}
This work presents a unique combination of an boost converter run by a set of two photovoltaic panels (PV) with a MPPT, suitable to guarantee MPP even under partial shadowed conditions, managed by an adaptive neuro fuzzy inference system (ANFIS) trained by the training data derived from a Perturb and observation $(\mathrm{P} \& \mathrm{O})$ conventional algorithm. The single phase cascaded $\mathrm{H}$ bridge five-level inverter (CHI) driven by the individual outputs of the boost converter, with selective harmonic elimination scheme to eliminate typically the seventh order harmonics. Simulation was carried out in the MATLAB/SIMULINK environment validated the proposed scheme. It has been thus established; by both simulations the ANFIS model of MPPT scheme outperforms other schemes of conventional control algorithm.
\end{abstract}

Copyright (C) 2018 Institute of Advanced Engineering and Science. All rights reserved.

\section{Corresponding Author:}

T. Ramesh,

Department of EEE,

Karpagam Academiy of Higher Education,

Coimbatore, Tamil Nadu, India

Email: your.ramesh@gmail.com

\section{INTRODUCTION}

The PV array power and current characteristics are highly nonlinear under partially shaded condition [1]. There are multiple peaks in V-P characteristic curve under partially shaded condition. The conventional MPPT algorithms such as hill climbing perturb and observation (P\&O) and incremental conductance (INC) algorithm fails to track the global MPP in partially shaded condition as explained [2]. The effects of partial shading on PV array characteristics [3]. The use of conventional MPPT algorithm in partial shading condition on PV array causes significant losses in PV output power [4]. However, intelligence algorithms like, artificial neural net work (ANN) [5], fuzzy-GA Based Controller [6] is efficient in tracking the MPP under partial shaded condition as explained. The output power of PV array varies with surrounding conditions such as change in irradiation and temperature [7]. The P\&O and INC algorithms have irregular behavior in case of rapidly changing irradiation. Both $\mathrm{P} \& \mathrm{O}$ and INC cannot distinguish a local maximum from a global maximum [8].

In case of shaded conditions, these local maxima do occur in the V-P characteristic of a solar panel and operating at a local maximum could mean reduced power output, as is shown [9]. The DC/DC converter is required to transfer power from PV array to load with high efficiency [10]. The total harmonic distortion (THD) minimization on output voltage of the multilevel inverters offers high quality output waveform to interface with PV system as discussed [11]. The duty cycle to the inverter is generated by selective harmonic elimination pulse with modulation (SHE-PWM) technique implemented in cascaded H-bridge multilevel inverter as explained [12]. In this work, the ISSBC is followed by a, single phase CHI driven by the individual DC outputs of the ISSBC, with SHE scheme to eliminate typically the higher order harmonics [13]. One approach to deal with the complex real world problems is to combine the use of two or more 
techniques in order to combine their different strengths and overcome each other weakness to generate hybrid solutions as discussed [14]. In this work the attention will be focused on matlab simulation ANFIS MPPT techniques, considering different weather and partially shaded conditions [15]. The values of the above algorithm have been evaluated.This work proposed hybrid techniques ANFIS to identify the reconfiguration and MPPT issues of PV under partial shaded conditions in distributed stand-alone PV system. The attention will be focused on simulation.

\section{PV ARRAY MODELING}

A $150 \mathrm{~W}$ rated PV panel consisting of 72 multi-crystalline silicon solar cells in series is used in this work. In this model, a PV cell is represented by a current basis in parallel with a diode and a series resistance. The current equation is given by (1):

$$
I=I_{p v}-I_{0} \quad\left[\exp \frac{q v}{a k T}-1\right]
$$

Where IPV = current generated by the incident light, $\mathrm{T}=$ Temperature of the PN junction, $\mathrm{a}=$ diode ideality constant $\mathrm{I} 0$, = leakage current of the diode, $\mathrm{q}=$ electron charge $1.6021 \times 10-19 \mathrm{C}, \mathrm{k}=$ Boltzmann constant $(1.38 \times 10-23 \mathrm{~J} / \mathrm{K})$.

\section{DC-DC CONVERSION}

The output power from PV array is subjected to environment conditions such as irradiance, temperature etc. Hence, in order to overcome these difficulties, it is necessary to have some control strategies or energy storage systems. The converters and inverters are used to integrate the PV array, energy storage and different types of loads. In this research work boost converter and CHI are used.

The main part of MPPT hardware is a DC-DC converter the block diagram shown in Figure 1. It tracks the MPP and guarantees the DC link voltage under low irradiance condition. The boost converter increases the output power of PV array with high efficiency.

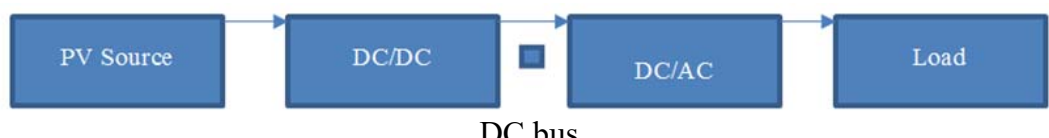

Figure 1. Block diagram of PV system with DC/DC and DC/AC conversion system

\section{SINGLE PHASE CHI INVERTER}

In this work, the boost converter is followed by CHBMLI. Multilevel inverter is used for applications require high quality of $\mathrm{AC}$ waveform. The selective harmonic elimination pulse with modulation technique is implemented to generate the switching duty cycle for CHI. Equation (2) shows the contents of the output voltage at infinite frequencies, module voltage $V_{p v 1^{-}} V_{p v 2}$ and respective switching angles $\alpha_{1^{-}}-\alpha_{2}$.

$$
V_{a b}(\alpha)=\sum_{n=1,5,7,11 \ldots}^{\infty}\left[\frac{4}{\pi \cdot n} \cdot\left(V_{p v 1} \cos \left(n \cdot \alpha_{1}\right)+V_{p v 2} \cos \left(n \cdot \alpha_{2}\right)\right]\right.
$$

Where,

$V_{p v} 1, V_{p v^{-}}$module voltage

$\alpha_{1}, \alpha_{2}$-switching angles which must satisfy the condition,

$0<\alpha_{1}<\alpha_{2}<\pi / 2$

$n$ - Odd harmonic order

The switching angles $\left(\alpha_{1}, \alpha_{2}\right)$ lie between zero and $\pi / 2$. The collected set of data is trained in ANN simulink tool and exported to the system. The ANN is trained to output the set of angles for each input voltage. The simulink diagram of single phase 5 levels CHBMLI is shown in Figure 2.

Analysis of ANFIS MPPT Controllers for Partially Shaded Stand alone Photovoltaic System ... (T.Ramesh) 


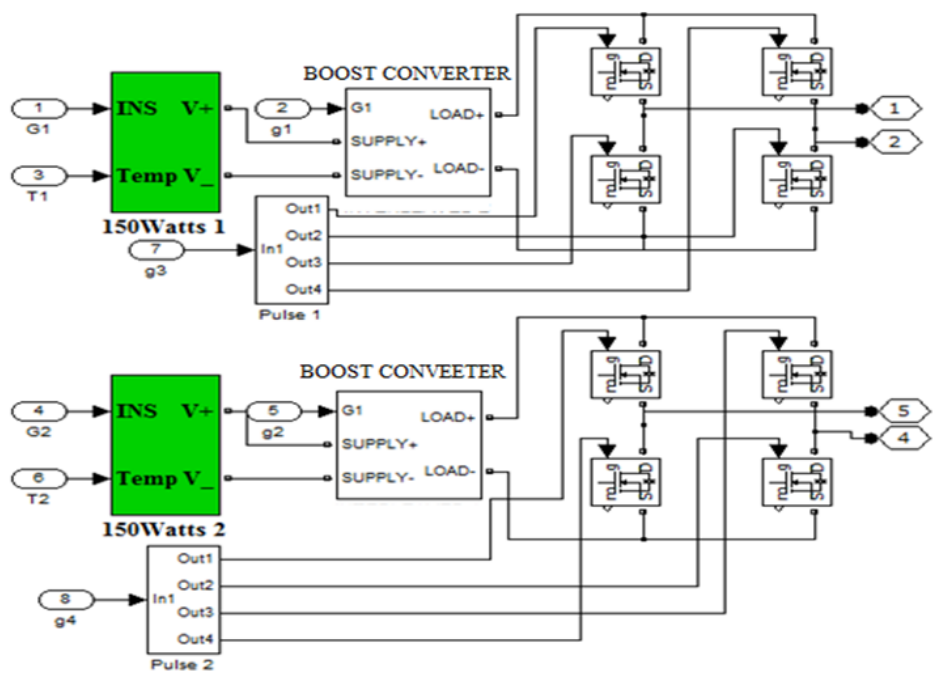

Figure 2. Simulink diagram of CHBMLI

\section{MPPT CONTROL ALGORITHMS}

The objective of MPPT algorithm is to draw maximum power from PV modules for changing solar irradiance $(\mathrm{G})$ and temperature $(\mathrm{T})$ conditions. With that aim, PV modules are matched to the load and maximum power generation is ensured. The boost converter serves the purpose of transferring maximum power from the solar PV module to the load.

\subsection{P\&O Algorithm}

In this work, $\mathrm{P} \& \mathrm{O}$ algorithm is employed to continuously track the MPP by perturbs the duty cycle in order to drive the boost converter output power to its maximum shown in Figure 3. The algorithm uses voltage and current measurements to calculate change in power $(\Delta P)$. If $\Delta P>0$ after perturbation of duty cycle, then perturb the duty cycle in the same direction. If $\Delta P<0$, then the perturbation of duty cycle is made in opposite direction. The ISSB converter consists of switching devices which operates depending on the applied gate signal. The gate signal for the switching device can be obtained by changing the duty cycle by this P\&O MPPT algorithm. This method is simple and easy to implement. However, the operating point of PV array oscillates around the MPP and this method fails to track the MPP under rapidly changing insolation.

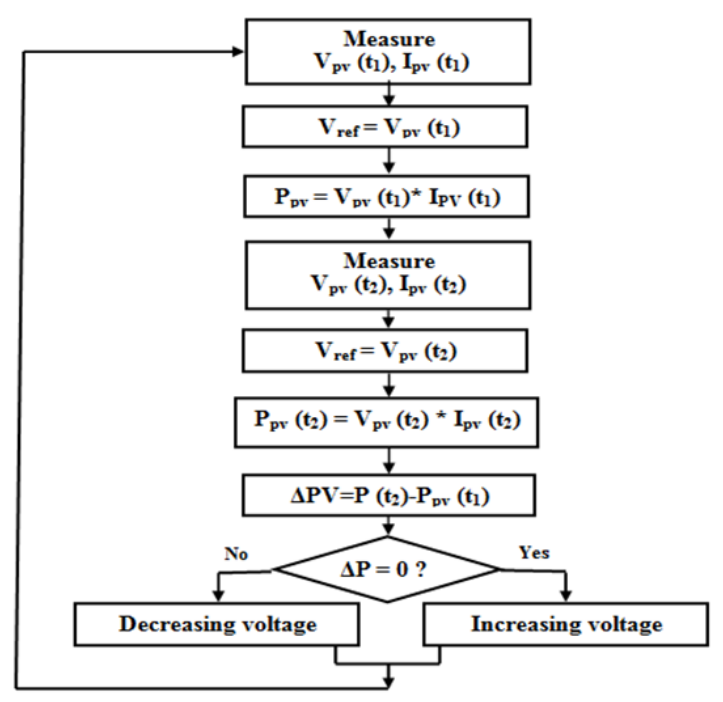

Figure 3. P\&O algorithm 
This system is commonly used because of its simplicity and ease of implementation Furthermore, P\&O (with a small step size) in nominal conditions can have MPPT efficiencies mostly the same like other complex techniques, and still easier implementation. However, the drawback of this technique is that the operating point of the PV array oscillates around the MPP.

\subsection{ANFIS MPPT Algorithm}

Combining fuzzy logic and neural networks is a powerful tool in control, forecast and modeling of composite systems such as photovoltaic systems. Neural networks are based on statistics training, while fuzzy logics are based on skilled knowledge. ANFIS constructs an input output mapping based both on human being information and on generated input output data pairs by using hybrid algorithm that is the arrangement of the least-squares and back propagation gradient method.

In this process pair of input-output data sets under different weather conditions is collected using P\&O MPPT algorithm and trained by ANFIS controller. The training data set for ANFIS is obtained by varying the working temperature in stair of $5^{\circ} \mathrm{C}$ from $10^{\circ} \mathrm{C}$ to $55^{\circ} \mathrm{C}$ and the solar irradiance level in a stair of $25 \mathrm{~W} / \mathrm{m}^{2}$ from $200 \mathrm{~W} / \mathrm{m}^{2}$ to $1050 \mathrm{~W} / \mathrm{m}^{2}$. There is 2000 training data set and 500 epochs are used to train the ANFIS reference model. The training error condensed to approximately $0.009 \%$. Flow chart for execution of ANFIS based maximum power point is shown in Figure 4. The deliberate ANFIS organizer has also two inputs voltage $V(Z)$, current $I(Z)$, and one output duty cycle (D). The two input $V$ $(Z)$ and $I(Z)$ variables produce a control signal $D(Z)$, which is execution to the ISSB converter to adjust the duty cycle. The proposed ANFIS controller is conscious to take advantage of P\&O simplicity and eliminate the drawback of P\&O MPPT such as slow convergence, oscillation around the MPP, and shifting of operating point from optimal point during cloudy days.

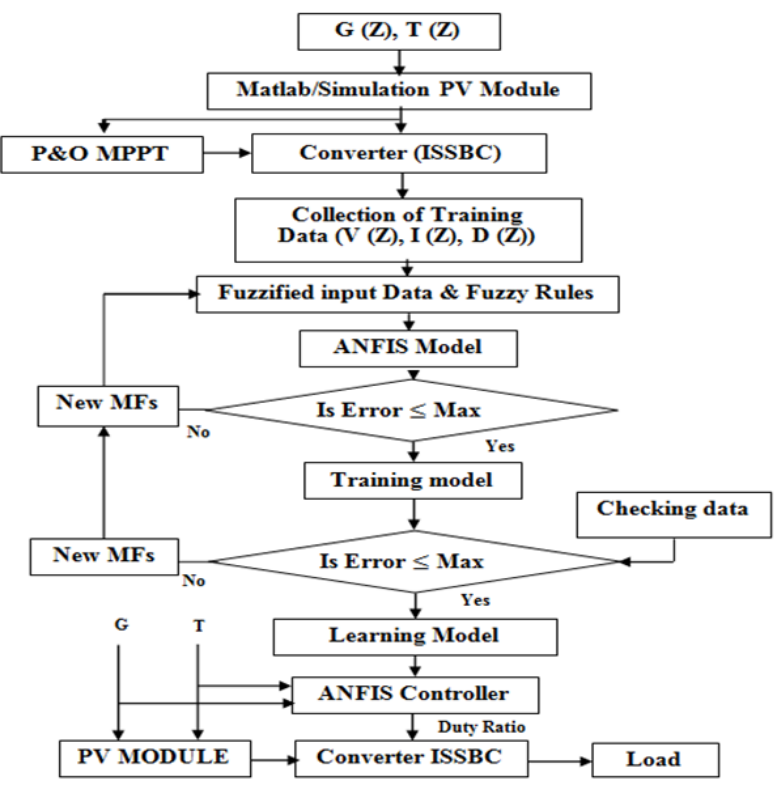

Figure 4. Flow chart of ANFIS based MPPT algorithm

\section{SIMULATION RESULTS}

The simulink software validates the performance of the MPPT intelligence techniques under different operating conditions. The parameters considered in the standard test condition are irradiance of $1000 \mathrm{~W} / \mathrm{m}^{2}$ and cell temperature of $25^{\circ} \mathrm{C}$. The simulink diagram of the proposed system is shown in Figure 5. The Figure 6 and 7 shows the I-V and V-P curves of PV modules in which the PV panel 1 is always kept at insolation of $G_{1}=1000 \mathrm{~W} / \mathrm{m}^{2}$ and the PV panel 2 is changed from $1000 \mathrm{~W} / \mathrm{m}^{2}$ to $\mathrm{G}_{2}=800 \mathrm{~W} / \mathrm{m}^{2}, 600 \mathrm{~W} / \mathrm{m}^{2}$ and $400 \mathrm{~W} / \mathrm{m}^{2}$. In order to achieve the maximum power point of PV modules, P\&O and ANFIS MPPT controller has been developed using Matlab Simulink model. The simulation results are presented for the following different configurations as shown in Table 1.

Analysis of ANFIS MPPT Controllers for Partially Shaded Stand alone Photovoltaic System ... (T.Ramesh) 


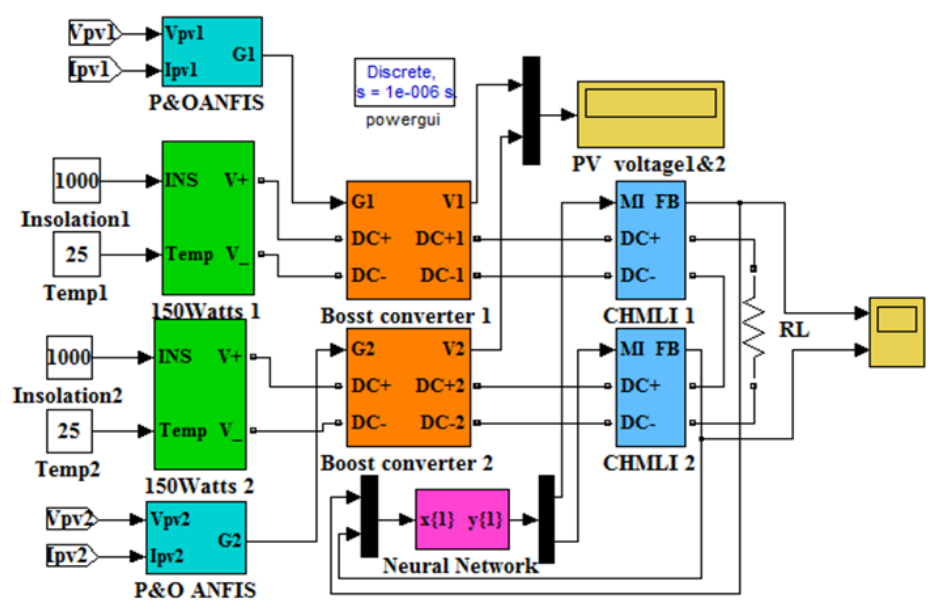

Figure 5. Simulation diagram of the system

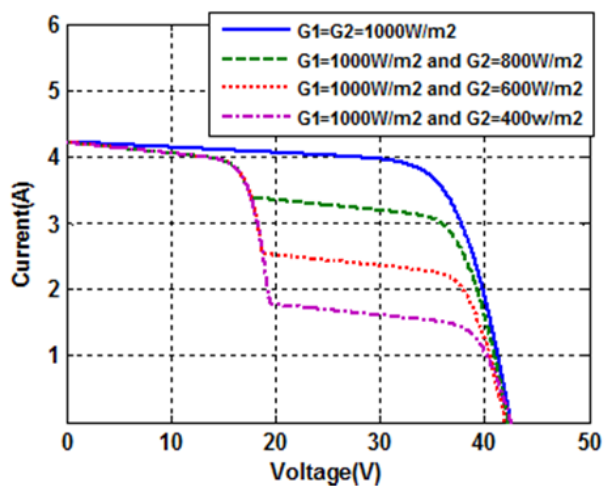

Figure 6. I-V curves at $25^{\circ} \mathrm{C}$

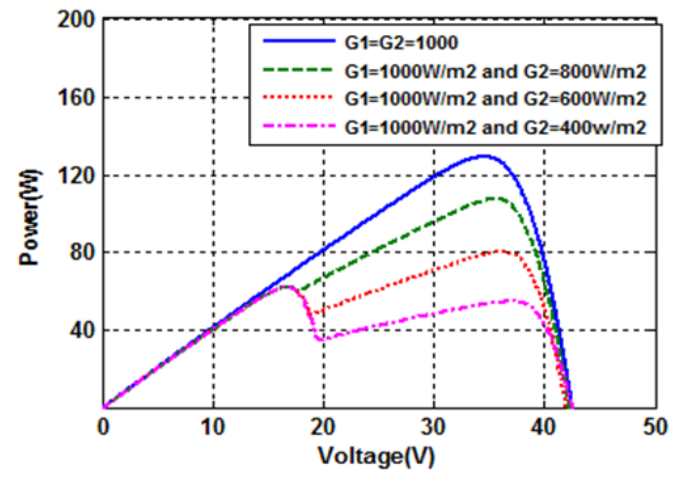

Figure 7. P-V curves at $25^{\circ} \mathrm{C}$

Table 1. Simulation configurations

\begin{tabular}{|c|c|c|c|}
\hline \multirow{2}{*}{ S.No } & \multicolumn{2}{|c|}{ Configuration } & \multirow[t]{2}{*}{ Algorithms } \\
\hline & Simulation & Converter/Inverter & \\
\hline
\end{tabular}

\subsection{Slowly Changing Irradiation with (4\%) Ripple}

In view of a real condition, the solar irradiance varies from a certain minimum value to the maximum value and then goes down to a dissimilar minimum value. To simulate a real time circumstances, the irradiation is slowly varied with (4\%) ripple consequently as shown in Figure 8 (a). The simulated output voltage and current is shown in Figure 8 (b). The simulated DC output power for P\&O and ANFIS is shown in Figure 8 (c) and efficiency is shown in Figure 8 (d). The PV module is connected with resistive load of $16.75 \mathrm{ohms}$ and interfaced through boost converter. The solar irradiance varied from $200 \mathrm{~W} / \mathrm{m}^{2}$ to a peak value of $1080 \mathrm{~W} / \mathrm{m}^{2}$ and then decreases again to $200 \mathrm{~W} / \mathrm{m}^{2}$ with $4 \%$ ripple, and cell temperature of $25^{\circ} \mathrm{C}$ and simulation time of 400s. The range of the DC voltage, duty cycle, response time, efficiency and DC output power for different algorithms are tabulated in Table 2. As shown in Table 2, the simulated output power for P\&O MPPT is $107.30 \mathrm{~W}$ and $120 \mathrm{~W}$ for ANFIS MPPT. It is evident from Table 2, ANFIS extract the MPP voltage of $44.70 \mathrm{~V}$ and the DC output power of $138.50 \mathrm{~W}$ with efficiency of $98.50 \%$ and also the response time to track MPP is $10 \mathrm{~s}$ which is comparatively less than other algorithms. 


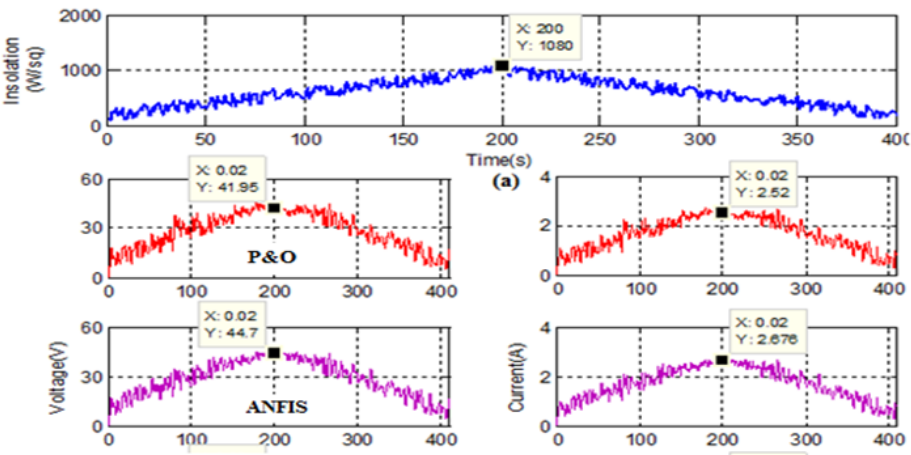

(b)

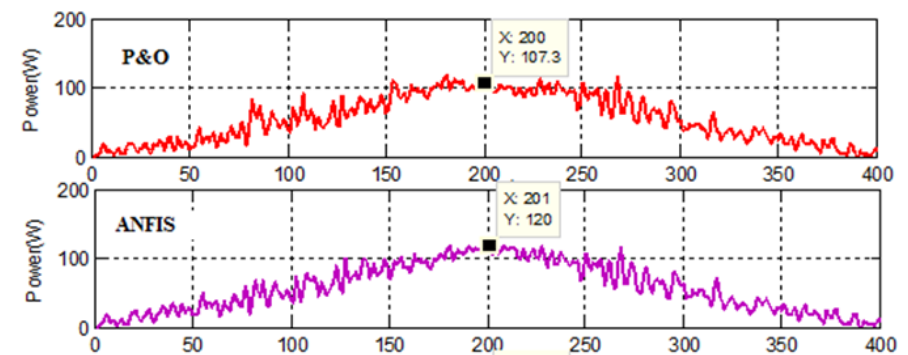

(c)

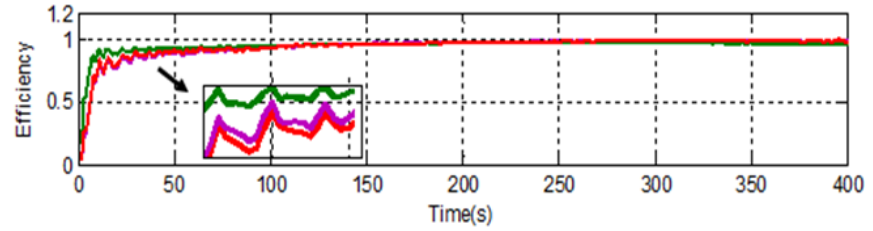

(d)

Figure 8. Simulation of slowly changing irradiance (a) insolation (b) voltage and current (c) Power (d) Efficiency

Table 2. Simulation results for slowly variation in irradiation

\begin{tabular}{lcccccc}
\hline \multicolumn{1}{c}{ MPPT algorithm } & $\begin{array}{c}\text { Voltage } \\
(V)\end{array}$ & $\begin{array}{c}\text { Current } \\
(A)\end{array}$ & $\begin{array}{c}\text { Power } \\
\left(W_{d c}\right)\end{array}$ & $\begin{array}{c}\text { Efficiency } \\
(\%)\end{array}$ & $\begin{array}{c}\text { Duty cycle } \\
(\mathrm{MI})\end{array}$ & $\begin{array}{c}\text { Response time } \\
\text { range } \\
(\mathrm{s})\end{array}$ \\
\hline P\&O & 41.95 & 2.52 & 107.30 & 96.50 & 0.23 & 14 \\
ANFIS & 44.70 & 2.67 & 120.00 & 97.00 & 0.23 & 12 \\
\hline
\end{tabular}

\subsection{PARTIAL SHADED CONDITION}

\subsubsection{Dynamic variation of insolation}

In practice, the deviation in the irradiation is observed, due to shadowing effects of tree leaves, dust etc. It is very difficult to test all the non-uniform irradiance conditions, hence only one circumstance is selected to illustrate the tracking ability of the MPPT algorithms. The shading patterns SD1 and SD2 are shown in Table 3. For SD1, the irradiance on the two PV panels is uniform with insolation of $400 \mathrm{~W} / \mathrm{m}^{2}$, as a result, only one peak exists in the V-P characteristics curve of the PV array. For SD2, there are two peaks in the V-P characteristics since the irradiance on the two panels is non-uniform with insolation of $\mathrm{G}_{1}=400 \mathrm{~W} / \mathrm{m}^{2}$ and $\mathrm{G}_{2}=800 \mathrm{~W} / \mathrm{m}^{2}$. The cell temperature is maintained constant at $\mathrm{T}=25^{\circ} \mathrm{C}$ for both SD1 and SD2 conditions. The detailed simulation results are shown in Figure 9. From Figure 9, it is observed that when the shading pattern changes from uniform condition to partial shading condition at 200s (middle of the x-axis), the proposed MPPT algorithms can find the global MPP for the new shading pattern. When the case change from SD1 to SD2, the power changes from $44.65 \mathrm{~W}$ to $114.8 \mathrm{~W}$ for P\&O MPPT algorithm and the power changes from $53.9 \mathrm{~W}$ to $127.8 \mathrm{~W}$ for ANFIS algorithm, negligible oscillations when compared to P\&O and ANFIS algorithms. Thecredible efficiency, response time, output voltage, power and duty cycle rate of each 
technique under the rapidly changing conditions of irradiance are presented in Table 4. The MPPT efficiency is calculated for all the MPPT algorithms. Figure 9 (c) shows the MPPT efficiency against time. From this, it is observed that the proposed ANFIS algorithm is more efficient than P\&O MPPT algorithms.
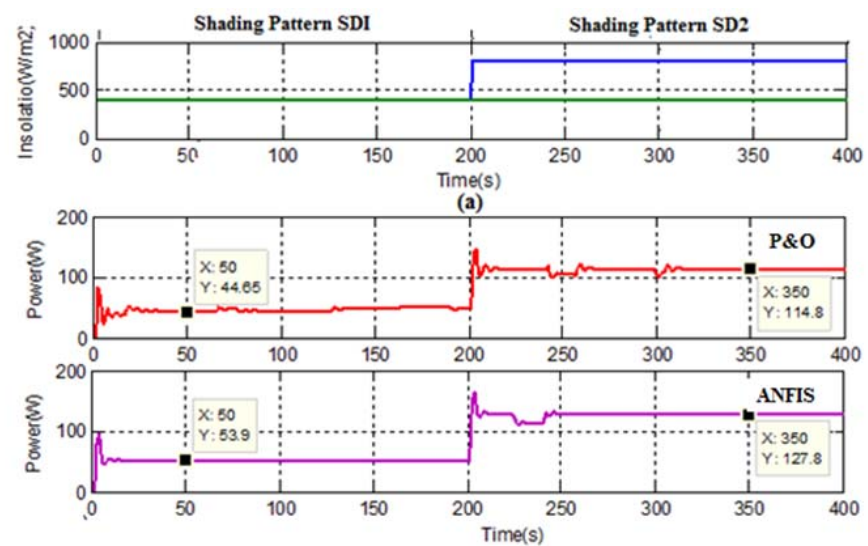

(b)

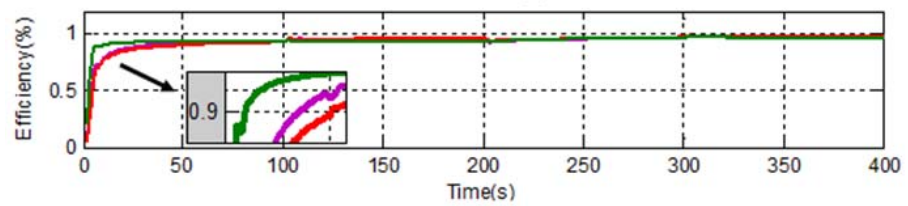

(c)

Figure 9. Dynamic behavior partial shaded power outputs of the MPPTs (a) Insolation (b) Power (c) efficiency

Table 3. Dynamic response of shaded insolation pattern

\begin{tabular}{llccc}
\hline \multirow{2}{*}{ Pattern } & \multicolumn{1}{c}{ Time configuration } & Insolation & Insolation & Cell Temperature \\
$\mathrm{G}_{2}\left(\mathrm{~W} / \mathrm{m}^{2}\right)$ & $\mathrm{G}_{1}\left(\mathrm{~W} / \mathrm{m}^{2}\right)$ & 400 & 25 \\
$\mathrm{SD} 1$ & from $\mathrm{t}=0 s$ to $\mathrm{t}=200 s$ & 400 & 800 & 25 \\
$\mathrm{SD} 2$ & from $\mathrm{t}=200 s$ to $\mathrm{t}=400 s$ & 400 & 800 & 25 \\
\hline
\end{tabular}

Table 4. Dynamic response of simulation

\begin{tabular}{lccccc}
\hline \multirow{2}{*}{ MPPT } & Pattern & $\begin{array}{c}\text { Power } \\
\left(P_{d c}\right)\end{array}$ & MI & Response Time (s) & $\begin{array}{c}\text { Efficiency } \\
(\%)\end{array}$ \\
\hline \multirow{2}{*}{ P\&O } & SD1 & 44.65 & 0.21 & 10 & 96.10 \\
\multirow{2}{*}{ ANFIS } & SD2 & 114.8 & 0.19 & 10 & 96.70 \\
& SD1 & 53.90 & 0.22 & 15 & 97.10 \\
& SD2 & 127.80 & 0.21 & 15 & 97.50 \\
\hline
\end{tabular}

\subsubsection{Partially shaded and non-shaded solar irradiation connected with inverter}

To analyze the performances of the P\&O, and ANFIS algorithms under non-shaded and shaded conditions, the two PV modules, boost converter and CHI are used. The RL load $(\mathrm{R}=16.75$ ohms and $\mathrm{L}=20$ $\mathrm{mH}$ ) is connected to CHI. Under non- shaded (balanced) condition the solar irradiance of both PV arrays are constant $\left(\mathrm{G}_{1}=\mathrm{G}_{2}=800 \mathrm{~W} / \mathrm{m}^{2}\right)$. Under the partial shaded (unbalanced) condition the solar irradiance of two PV modules are $G_{1}=800 \mathrm{~W} / \mathrm{m}^{2}$ and $\mathrm{G}_{2}=400 \mathrm{~W} / \mathrm{m}^{2}$ respectively. The simulated AC output voltage and its harmonic spectrum under non-shaded and shaded condition are shown in Figure 10 and Figure 11 for P\&O and ANFIS controllers. The SHE-PWM technique is used in CHBMLI and the seventh harmonics is eliminated. From Figure 10 and Figure 11, it is observed the THD is 59.16\% for P\&O, 47.54\% for ANFIS and $29.13 \%$ can be seen the seventh harmonics is eliminated. The simulation results of the converter output DC voltage, inverter AC stepped output voltage and THD parameters are shown in Table 5. From the Table 5 , it is reveal that, the ANFIS algorithm extracted the maximum power of $63.48 \mathrm{~W}$ in PV1 and $62.39 \mathrm{~W}$ in PV2 and the inverter RMS voltage is $51.87 \mathrm{~V}$ with $\mathrm{G}_{1}=\mathrm{G}_{2}=800 \mathrm{~W} / \mathrm{m}^{2}$ and $61.97 \mathrm{~W}$ for PV1 and $29.99 \mathrm{~W}$ for 
PV2 and the inverter RMS voltage is 40.29 Vwith $\mathrm{G}_{1}=800 \mathrm{~W} / \mathrm{m}^{2}$ and $\mathrm{G}_{2}=400 \mathrm{~W} / \mathrm{m}^{2}$. The ANFIS algorithm outperforms all other algorithms in terms of power, THD and inverter voltage.

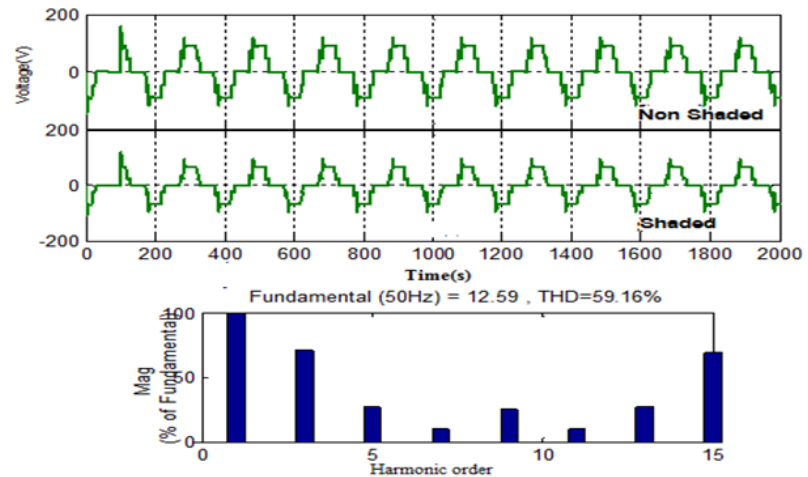

Figure 10. Simulation results for $\mathrm{P} \& \mathrm{O}$ under non-shaded and partial shaded output voltage and corresponding harmonic spectrum
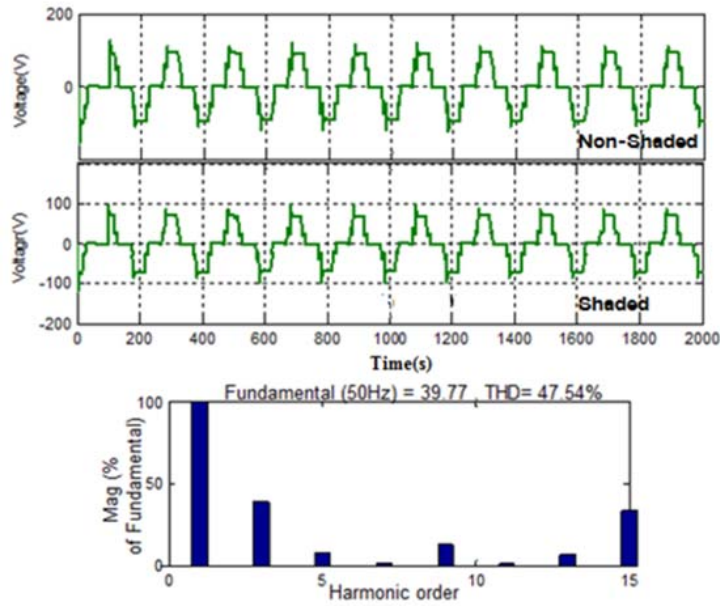

Figure 11. Simulation results for ANFIS under non-shaded and partial shaded output voltage corresponding harmonic spectrum

Table 5. Simulation result of partially shaded and non-shaded condition

\begin{tabular}{|c|c|c|c|c|c|c|}
\hline \multirow[b]{2}{*}{ MPPT } & \multirow{2}{*}{$\begin{array}{c}\text { Insolation } \\
\left(\mathrm{G}_{1} / \mathrm{G}_{2}\right) \\
\mathrm{W} / \mathrm{m}^{2} \text { at } \mathrm{T}=25^{\circ} \mathrm{C}\end{array}$} & \multicolumn{2}{|c|}{ Boost convrter } & \multicolumn{3}{|c|}{$\mathrm{CHI}$} \\
\hline & & $\begin{array}{l}\mathrm{PV}_{1} \\
(\mathrm{~V})\end{array}$ & $\begin{array}{l}\mathrm{PV}_{2} \\
(\mathrm{~V})\end{array}$ & $\begin{array}{c}\text { Stepped } \\
\text { Voltage }(\mathrm{V})\end{array}$ & $\begin{array}{l}\mathrm{V}_{\text {rms }} \\
(\mathrm{V})\end{array}$ & $\begin{array}{c}\text { THD (\%) } \\
\text { (Non-shaded) }\end{array}$ \\
\hline $\mathrm{P} \& \mathrm{O}$ & $\begin{array}{l}800 / 800 \\
800 / 400\end{array}$ & $\begin{array}{l}61.57 \\
60.13\end{array}$ & $\begin{array}{c}60.6 \\
28.60\end{array}$ & $\begin{array}{l}74.47 \\
55.65\end{array}$ & $\begin{array}{l}39.25 \\
44.68\end{array}$ & 59.16 \\
\hline ANFIS & $\begin{array}{l}800 / 800 \\
800 / 400\end{array}$ & $\begin{array}{l}62.03 \\
61.03\end{array}$ & $\begin{array}{l}61.95 \\
29.32\end{array}$ & $\begin{array}{c}74.7 \\
56.39\end{array}$ & $\begin{array}{l}51.50 \\
39.78\end{array}$ & 47.54 \\
\hline
\end{tabular}

\section{CONCLUSION}

This work analyzes the performance of P\&O and ANFIS MPPT algorithms in stand-alone PV system. The configuration for the proposed system is designed and simulated using MATLAB/Simulink. The acceptable results are summarized as follows. The proposed system shows a good dynamic performance to track the MPP of the PV units even under the rapid change of the irradiation and cell temperature. It has been observed that the boost converter can be more efficient than the conventional and maximum efficiency at all load conditions. In this study boost converter is selected to achieve low cost, simple control structure and

Analysis of ANFIS MPPT Controllers for Partially Shaded Stand alone Photovoltaic System ... (T.Ramesh) 
high efficiency. The ANFIS can provide the overall efficiency higher than P\&O algorithms. The CHI integrates with SHE ANN modulation technique improves the output voltage quality and reduction in THD percentage even in unbalanced insolation of PV modules with the ANFIS based MPPT algorithm.

\section{REFERENCES}

[1]. Salmi Hassan, Badri Abdelmajid, Zegrari Mourad, Sahel Aicha, Baghdad, 'Abdenaceur An Advanced MPPT Based on Artificial Bee Colony Algorithm for MPPT Photovoltaic System under Partial Shading Condition' International Journal of Power Electronics and Drive System Vol. 8, No. 2, June 2017, pp. 647-653.

[2]. Esram, T \& Chapman, PL, 'Comparison of Photovoltaic Array Maximum Power Point Tracking Techniques', IEEE Transaction on Energy Conversion, vol.22, pp.439-449,2007.

[3]. Yi-Hua Liu, Chun-Liang Liu, Jia-Wei Huang \& Jing-Hsiau Chen, 'Neural-Network-Based Maximum Power Point Tracking Methods for Photovoltaic Systems Operating Under Fast Changing Environments', Solar Energy, vol.89, pp.42-53,2013.

[4]. Rozana Alik, Awang Jusoh, Tole Sutikno A, 'Study of Shading Effect on Photovoltaic Modules with Proposed P\&O Checking' Algorithm International Journal of Electrical and Computer Engineering, vol. 7 (1), pp.29-40,2017.

[5]. Whei-Min Lin, Chih-Ming Hong \&ChiungHsing Chen 'Neural Network Based MPPT Control of a Stand-alone Hybrid Power Generation System', IEEE Transactions on Power Electronics, vol.26, pp.3571-3581, 2011.

[6]. Raghu Thumu, K. Harinadha Reddy 'A Review on Fuzzy-GA Based Controller for Power Flow Control in Grid Connected PV System' Algorithm International Journal of Electrical and Computer Engineering, vol. 7 (1), pp125-133, 2017.

[7]. Xianwen Gao, Shaowu Li \&Rongfen Gong, 'Maximum Power Point Tracking Control Strategies with Variable Weather Parameters for Photovoltaic Generation Systems', Solar Energy, vol.93, pp.357-367,2013.

[8]. Robert CN, Pilawa-Podgurski\& David Perrault, J, 'Sub module Integrated Distributed Maximum Power Point Tracking for Solar Photovoltaic Applications',IEEE Transactions on Power Electronics, vol.28, pp.2957$2967,2013$.

[9]. Shiqiong Zhou, Longyun Kang, Jing Sun, GuifangGuo, Bo Cheng, Binggang Cao\&Yiping Tang, 'A Novel Maximum Power Point Tracking Algorithms for Stand-alone Photovoltaic System', Internation Journal of Control Automation Systems, vol.8, pp.1364-1371,2010.

[10]. Meryem Oudda, Abdeldjebar Hazzab, 'Photovoltaic System with SEPIC Converter Controlled by the Fuzzy Logic' International Journal of Power Electronics and Drive System (IJPEDS), Vol.7, No.4, pp. 283-293, 2016.

[11]. FaeteFilho, Leon, M, Tolbert \& Yue Cao, 'Real-Time Selective Harmonic Minimization for Multilevel Inverters Connected to Solar Panels Using Artificial Neural Network Angle Generation', IEEE Transactions on Industry Applications, vol.47, pp.2117-2124, 2011.

[12]. Mohd Ruddin Ab Ghanil, Nabil Farah, Jurifa Lazi, M.R.Tamjis, 'Investigation Study of Three-Level Cascaded Hbridge Multilevel Inverter’ TELKOMNIKA, Vol.15, No.1, pp.125-137, 2017.

[13]. Tsang, KM \& Chan, WM, 'Three-Level Grid-Connected Photovoltaic Inverter with Maximum Power Point Tracking', Energy Conversion and Management, vol.65, pp.221-227, 2013.

[14]. Ravinder, KK, MdFahim Ansari \&Shimi, SL, 'Design and Implementation of ANFIS Based MPPT Scheme with Open Loop Boost Converter for Solar PV Module', Internation journal of Advanced Research in Electrical and Electronics and Instrumentation Engineering, vol.3, pp.6517-6524, 2014.

[15]. Mellit, A \& Kalogeria, SA, 'ANFIS-Based Modeling for Photovoltaic Power Supply System', Renewable Energy, vol.36, pp.50-258, 2011.

\section{BIOGRAPHIES OF AUTHORS}

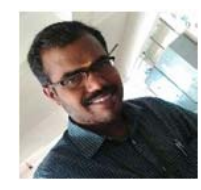

T.Rameshreceived the B.E. and M.E. degrees from Anna University Chennai in 2007 and 2009, respectively, His areas of interest include power systems and soft computing techniques. Currently, he is an Assistant Professor in the Electrical\& Electronics Engineering Department, Karpagam University Coimbatore. Currently he is pursuing his Ph.D., in Anna University Chennai.

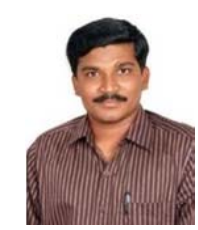

Dr.R.Saravanan working Tirumala Engineering College, Bogarm, Hyderabad, Telengana in Department of Electrical and Electronics Engineering. He obtained Ph.D. from Anna University Chennai in the year of 2016 His research interests are Power quality, FACTS devices and soft computing techniques.

IJRA Vol. 7, No. 2, June 2018: $140-148$ 